\title{
Characteristics Predicting a High Caregiver Burden in Patients with Vascular Cognitive Impairment: Using the Apriori Algorithm to Delineate the Caring Scenario [Corrigendum]
}

\author{
Jhang KM, Wang WF, Chang HF, Chang MC, Wu HH. The authors apologize for this error.
} Risk Manag Healthc Policy. 2021;14:1335-1351.

Page 1336, Patients and Methods section, second sentence, the text "(CCH IRB 160165)" should read "(CCH IRB 160615)".

\section{Publish your work in this journal}

Risk Management and Healthcare Policy is an international, peerreviewed, open access journal focusing on all aspects of public health, policy, and preventative measures to promote good health and improve morbidity and mortality in the population. The journal welcomes submitted papers covering original research, basic science, clinical \& epidemiological studies, reviews and evaluations, guidelines, expert opinion and commentary, case reports and extended reports. The manuscript management system is completely online and includes a very quick and fair peer-review system, which is all easy to use. Visit http://www.dovepress.com/testimonials.php to read real quotes from published authors. 